\title{
短波海洋レーダ観測データのエネルギー補正による波浪推定精度の向上

\author{
Improvement Accuracy of Wave Parameters Estimated with Energy Calibration \\ in HF Oceanographic Radar Data
}

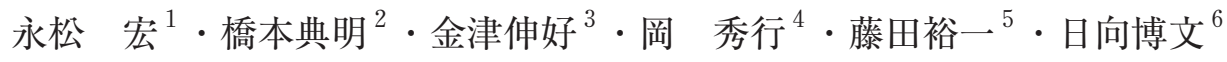 \\ Hiroshi NAGAMATSU, Noriaki HASHIMOTO, Nobuyoshi KANATSU \\ Hideyuki OKA, Yuiti FUJITA and Hirofumi HINATA
}

\begin{abstract}
The accuracy of HF radar-measured wave parameters along the coast of GOTO Islands is examined. Doppler spectra were obtained from two radars, measured at Takasaki-bana and Tsuwazaki, in winter (from December 2007 to January 2008). Using Barrick's method(1977), we estimated significant wave heights and periods from hourly Doppler spectra. A comparison of those estimated from two radars shows different wave height. Hence, we calibrated Doppler spectra so that the significant wave height from two radars might become equal height. Furthermore, we applied the calibrated Doppler spectra to a Bayesian method (Hashimoto and Tokuda, 1998). As a result, the wave parameters estimated by Bayesian method were in good agreement with those computed by WAM, and suitable directional wave spectra can be estimated.
\end{abstract}

\section{1. はじめに}

短波海洋レーダによる流況観測技術は，多くの実証観 測をもとに，既に確立・実用化されており，国土交通省 においては各地方整備局で流れ情報の提供や海上浮遊ゴ ミの回収効率化に向けた利活用を行っている（日向ら, 2008 など)。一方, 短波海洋レーダを利用した波浪観測 技術は, Wyatt (1990), Hisaki (1996), 橋本・徳田 （1998），橋本ら（2000，2008，2010）により実用的な波浪 推定法が提案されているものの, 実証観測例が少ないた め, 現地適用性の向上検討や実用化が遅れている.

欧米では1970年代に海洋レーダのドップラスペクトル デー夕をもとに有義波高・有義波周期を推定するバリッ ク法が開発された（Barrick, 1977）。その後, Wyattは, Chahine-Twomeyアルゴリズムにもとづいた方向スペクト ル解析法を開発し (Wyatt, 1990), この解析方法を EC MAST SCAWVEX project (Surface Current and Wave Variability Experiments）に適用し，高精度な方向スペク トルが推定された事例を報告している（Wyatt, 1997).

一方，わが国ではHisaki（1996）が開発した非線形最 適化法を用いる解析法, および橋本・徳田（1998）が開 発したベイズ法による方向スペクトル推定方法がある. Hisaki と橋本・徳田の方法は, 方向スペクトルを構成す

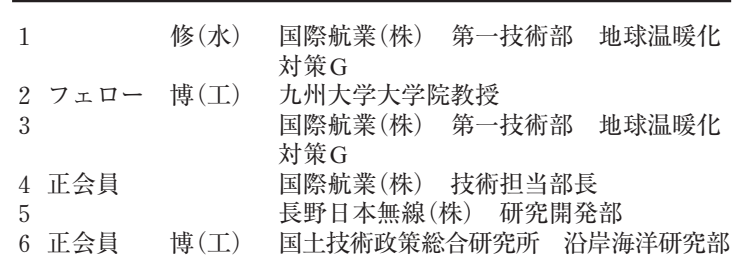

る周波数と方向角に関する各エネルギー成分を離散的な 一定值関数として扱い，これらを未知パラメータとする 非線形積分方程式を繰り返し計算によって解くものであ る. その後, 橋本ら $(2000,2008,2010)$ はベイズ法の適 用性を検討するため, 前述のSCAWVEX projectの観測デ ー夕にベイズ法を適用し, 適用性の確認や推定式の見直 しを行ってきた。しかし国内において外洋波浪を対象と した海洋レーダの観測データは少なく, 国内データへの 適用例はほとんどなかった。

そこで, 本研究では五島列島で観測された短波海洋レ ーダのドップラスペクトルデータをもとに, バリック法 およびベイズ法で有義波高・有義波周期を推定し, 第三 世代波浪推算法WAMの推算結果と比較した。この比較 をもとに，ドップラスペクトルデータにエネルギー補正 を施した。このエネルギー補正により, 海洋レーダと WAMによる有義波高・有義波周期, 方向スペクトルの 推定值が良く一致したことから, 今後の海洋レーダの波 浪観測実用化に寄与できると考え, 報告する次第である.

\section{Barrick（1972）によるバリック法}

海洋レーダで観測されるドップラスペクトルから波浪 パラメータを推定する試みはBarrick（1972, 1977）が最 初である. ドップラスペクトルの1次散乱成分 $\sigma^{(1)}(\omega)$ と 2 次散乱成分 $\sigma^{(2)}(\omega)$ はそれぞれ次式で表わされる。

$$
\begin{aligned}
\sigma^{(1)}(\omega)= & 2^{6} \pi k_{0}^{4} \sum_{m= \pm 1} S\left(-2 m k_{0}\right) \delta\left(\omega-m \omega_{B}\right) \cdots \cdots . . . \\
\sigma^{(2)}(\omega)= & 2^{6} \pi k_{0}^{4} \sum_{\mathrm{m}_{1}, \mathrm{~m}_{2}= \pm 1} \iint_{-\infty}^{\infty}|\Gamma|^{2} S\left(m_{1} k_{1}\right) S\left(m_{2} k_{2}\right) \\
& \times \delta\left(\omega-m_{1} \sqrt{g k_{1}}-m_{2} \sqrt{g k_{2}}\right) d p d q
\end{aligned}
$$


ここに $k_{0}$ は電波の波数べクトル, $S(k)=S\left(k_{x}, k_{y}\right)$ は波浪の 波数スペクトル， $\omega$ は角周波数， $\omega_{\mathrm{B}}$ はブラッグ角周波数, $m_{1}, m_{2}$ は $\omega$ の值域に依存する符号 $( \pm 1)$, 積分変数 $p$ と $q$ はそれぞれレーダのビーム軸方向およびそれと直交する 座標で, 散乱に関与する波の波数ベクトル $k_{1}=\left(p-k_{0}, q\right)$ と $k_{2}=\left(-p-k_{0},-q\right)$ とは $k_{1}+k_{2}=-2 k_{0}$ の関係がある.また， $\Gamma$ は結 合係数と呼ばれ，2つの波数成分 $k_{1}$ と $k_{2}$ の波浪成分が，2 次の散乱断面積に寄与する程度を表す。結合係数 $\Gamma$ は, 一般に, 電磁気学的な 2 次散乱による部分 $\Gamma_{E}$ と流体力学 的な 2 次散乱による部分 $\Gamma_{H}$ の和 $\left(\Gamma=\Gamma_{E}+\Gamma_{H}\right)$ で表され, それぞれ次式で与えられる。

$$
\begin{aligned}
& \Gamma_{E}=\frac{1}{2}\left[\frac{\left(k_{1} \cdot k_{0}\right)\left(k_{2} \cdot k_{0}\right) / k_{0}^{2}-2 k_{1} \cdot k_{2}}{\sqrt{k_{1} \cdot k_{2}}-k_{0} \Delta}\right] \ldots \ldots \ldots \ldots . . . \\
& \Gamma_{H}=\frac{-i}{2}\left[k_{1}+k_{2}-\frac{\left(k_{1} k_{2}-k_{1} \cdot k_{2}\right)\left(\omega^{2}+\omega_{B}^{2}\right)}{m_{1} m_{2} \sqrt{k_{1} k_{2}}\left(\omega^{2}-\omega_{B}^{2}\right)}\right]
\end{aligned}
$$

ここにムは海面の複素インピーダンスで, 絶対值の小さ な複素数である.

Barrickは，式（2）に含まれる2つの波数スペクトルの うち，波数の大きい波数スペクトルを 1 次散乱する波浪 成分を用いて一定值と仮定することにより積分の外に出 した。これは波高が高くなると，2次散乱の主要なエネ ルギーが 1 次散乱ピーク付近に卓越するため, 2 次散乱に 寄与する波長の小さい波浪成分波 $S\left(m_{2} k_{2}\right)$ は, 1 次散乱を 起こす波浪成分波（ブラッグライン）で近似できること による。このような小さい波浪成分波は波浪スペクトル の平衡領域に存在するため, ブラッグライン付近ではこ れらの波はほとんど一定とみなすことができ, 積分の外 に出せる.

その結果，式（1）は波数の短い波浪成分の波数スペ クトルに関する線形化した積分方程式で近似することが でき, Barrick は平均波高 $H_{A V E}$ と平均周期 $T_{A V E}$ を算出する 以下の式を提案した。

$$
\begin{aligned}
& H^{2}{ }_{A V E}=\frac{2 \int_{-\infty}^{+\infty}\left[\sigma^{(2)}(\omega) / w\left(\omega / \omega_{B}\right)\right] d \omega}{k_{0}^{2} \int_{-\infty}^{+\infty} \sigma^{(1)}(\omega) d \omega} \\
& T_{A V E}=\frac{2 \pi \int_{0,1}^{1,+\infty} \sigma^{(2)}\left(\omega_{B} v\right) / w(v) d \omega}{\omega_{B} \int_{0,1}^{1,+\infty}\left[(v-1) \sigma^{(2)}\left(\omega_{B} v\right) / w(v)\right] d v} \\
& w(v)=\frac{8|\bar{\Gamma}|^{2}}{k_{0}}
\end{aligned}
$$

ここに, $v$ は規格化した周波数 $\left(=\omega / \omega_{B}\right), w(v)$ はカッ プリング係数から求められる重み関数である.
上記の平均波の波高と周期を用いて，有義波高 $\left(H_{1 / 3}\right)$ と有義波周期 $\left(T_{1 / 3}\right)$ は以下に示す経験式を用いて求めら れる。

$$
\begin{aligned}
& H_{1 / 3}=1.6 H_{A V E} \\
& T_{1 / 3}=1.2 T_{A V E}
\end{aligned}
$$

\section{3. 橋本・徳田（1998）によるベイズ法}

橋本・徳田（1998）は，式（2）の非線形積分方程式 から直接，方向スペクトルを推定するベイズモデルを開 発した。

橋本・徳田は, 方向スペクトル $S(f, \theta)$ は一般に $S(f$, $\theta) \geqq 0$ であるが, $S(f, \theta)>0$ と仮定することにより, 方向 スペクトル $S(f, \theta)$ を指数部に離散的一定関数を有する指 数関数を用いて以下のように表現した（式（9)).

$$
S(f, \theta)=\sum_{i=1}^{M} \sum_{j=1}^{N} \exp \left(x_{i, j}\right) \delta_{i, j}(f, \theta) \cdots
$$

ここに, $x_{i, j}=\ln S\left(f_{i}, \theta_{j}\right), M$ は周波数分割数, $N$ は方 向分割数で, $\delta_{i},{ }_{j}(f, \theta)$ はデル夕関数で以下のような関 係を満たす。

$$
\delta_{i, j}(f, \theta)=\left\{\begin{array}{l}
1: f_{i-1} \leq f<f_{i} \text { and } \theta_{j-1} \leq \theta<\theta_{j} \ldots \\
0: \quad \text { その他 }
\end{array}\right.
$$

また橋本・徳田は, 指数部の離散的パラメータが滑ら かな連続関数である条件を先験条件として付加してお り, 先験条件の数は未知パラメータの数と等しく与えて いる.さらに式（2）の基礎式を満たす程度（観測值と 推定值の一致度）と方向スペクトルが滑らかな連続関数 であるという先験条件を満たす程度とのバランスを取る ため, 解の確からしさと滑らかさの両方の観点から望ま しい重み係数が得られるように, 赤池のベイズ型情報量 基準 $\mathrm{ABIC}$ を導入し，これを最小化することによって最 適な方向スペクトルを推定した.

本研究では, 橋本・徳田 (1998) と同様, 重み係数と して適当なパラメータ $u^{2}$ (超パラメータ）を用い, $u$ を 式（11）で示す格子探索法による繰り返し計算により 種々に変えて，最小の $\mathrm{ABIC}$ 探索を行った.

$$
u=a b^{m}(a=0.027, b=0.3, m=0,1,2,3, \cdots)
$$

\section{4. 五島列島での短波海洋レーダ観測}

本研究では五島列島西岸沖で観測された短波海洋レー ダデータを使用した。 この海洋レーダは, 海上漂流ゴミ の収束域予測を行うこと目的として, 高崎鼻と津和崎 （図-1および写真-1）に2007年 11 月に設置され，2010年2 


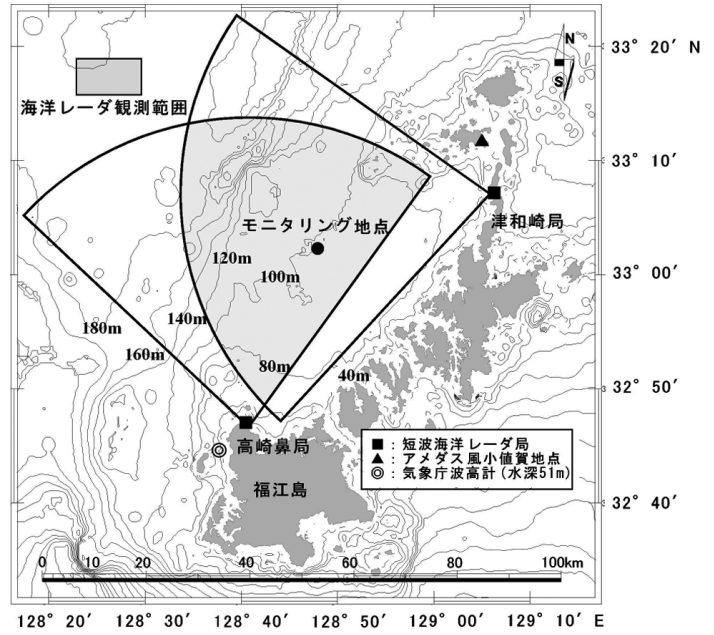

図-1 短波海洋レーダの観測対象海域
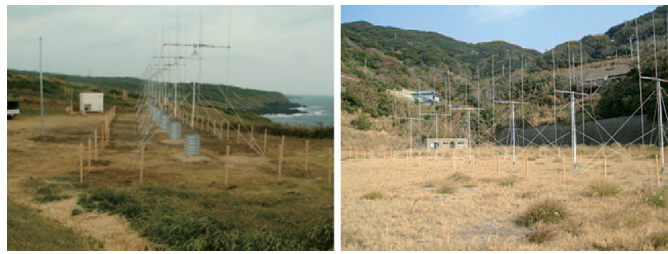

写真-1 短波海洋レーダアンテナ(左：高崎鼻局, 右：津和崎局)

表-1 短波海洋レーダの緒元

\begin{tabular}{c|c}
\hline & 項目 \\
\hline レーダの形式 & 送受切り替えFMCW \\
\hline 周波数 & $24.515 \mathrm{MHz}$ \\
\hline 掃引周波数幅 & $100 \mathrm{kHz}$ \\
\hline 周波数掃引間隔 & $0.5 \mathrm{~s}$ \\
\hline 送信出力 & $200 \mathrm{~W}$ \\
\hline 距離分解能 & $1.5 \mathrm{~km}$ \\
\hline アンテナ & デジタルビームフォーミング方式 \\
\hline ビーム幅 & 約 13 度 \\
\hline 観測範囲 & 土45度, 7.5 度ステップ
\end{tabular}

月まで観測が行われた，設置されたのは，国土技術政策 総合研究所が所有する長野日本無線製の送受切り替え $\mathrm{FMCW}$ 方式, 周波数 $24.5 \mathrm{MHz}$ の海洋レーダである(表-1). 五島列島では 1 時間に 1 回，10分間の観測を行い，ドッ プラスペクトルデー夕を取得した。本研究では，この観 測データのうち，2007年 12 月 10 日〜2008年1月 12 日の 冬季に観測されたものを解析した。また海洋レーダによ る波高，周期，および方向スペクトルは，高崎鼻と津和 崎の両局から約 $30 \mathrm{~km}$ の位置に設定したモニタリング地 点（図-1に○で示した）で推定を行い，後述する第三世 代波浪推算法WAMによる推定結果と比較した。

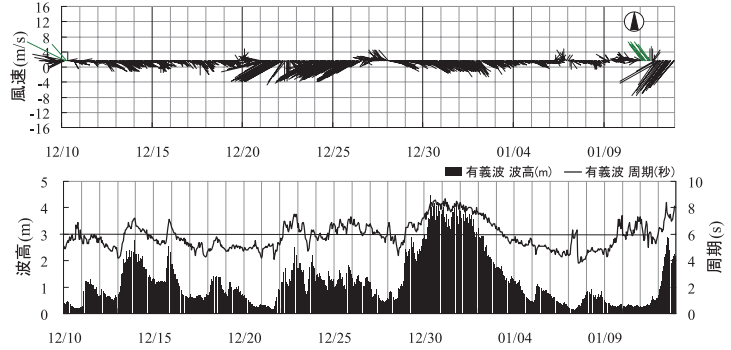

図-2 観測期間中の風（上段），波高・周期（下段）

解析期間中の五島列島沿岸での風況および波浪を図-2 に示す。風は，アメダス小值賀地点（図-1の山), 波浪 は気象庁の超音波式波高計（図-1の○）によるもので ある。

五島列島沿岸では, 解析期間を通じて北寄りの風が卓 越しており，有義波高が $3 \mathrm{~m}$ を越えた $12 / 30 \sim 1 / 1$ にかけ ては, 北西風が連吹した。

短波海洋レーダの観測範囲には，波高計が設置されて いない，そのため本研究では, 現地観測デー夕のかわり に, 高精度で沿岸波浪が推定できる第三世代波浪推算法 WAM（例えばKomenら，1994）により観測期間の波浪 場を推算し，海洋レーダによる推定值と比較することと した.

WAMでの波浪推算に用いた風は, 気象庁 GPVデー夕 のメソ客観解析值（MSMデー夕）である.MSMデー夕 は北緯 28～40 度, 東経 120～134度の範囲（113×97格 子）を 0.125 度間隔で内挿し，3時間毎のデータセットを 作成した。また解析領域は, 広領域（北緯 $28 \sim 40$ 度, 東経 $120 \sim 134$ 度, 格子間隔 0.125 度), 中領域（北緯 32 ～34 度，東経 126.5 130 度，格子間隔 0.03125 度)，五 島列島沿岸領域（北緯 32.5 33.5 度，東経 128～129.25 度，格子間隔 0.015625 度）の3 領域に分け，1way ネステ イングにより段階的に空間解像度を上げて波浪場を計算 した.

\section{5. 方向スペクトルの推定精度向上に関する検討}

\section{（1）ドップラスペクトルの観測例}

図-3 は，五島列島の短波海洋レーダ（周波数 $24.5 \mathrm{MHz}$ ) による図-1のモニタリング地点（の）のドップラスペク トルの一例で，津和崎局と高崎鼻局のそれぞれで観測さ れたドップラスペクトルを示している。ここに縦軸は対 数で表わしたスペクトルパワー（単位： $\mathrm{dB}$ ), 横軸は規 格化されたドップラ周波数を示す。この例では 2 局で観 測されたドップラスペクトルは, 同時刻に同一地点で得 られたものであるが，両者のエネルギーレベルは大きく 異なっていることがわかる. 


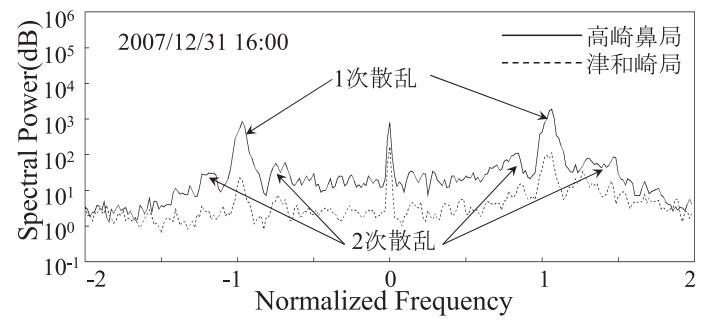

図-3 モニタリング地点のドップラスペクトル

\section{（2） 1 次散乱と 2 次散乱の分離}

ドップラスペクトルの2次散乱成分は, 共鳴条件を満 たす無数の周波数・方向成分波浪の組久合わせからの寄 与を表している。適切に 1 次散乱成分を除去し，2次散乱 成分を抽出することができれば，波高，周期および波向 の推定精度向上につながる.

本研究では, 1 次散乱成分の周辺で, 5 項から成る V字 部分（中央值が極小）を検出し，この中央值部分を 1 次 散乱と 2 次散乱の境界と判定することにより，1次散乱を 取り除いた。

\section{（3）バリック法による波浪推定}

観測されたドップラスペクトルから，前項（2）の方 法で取り出した2次散乱を用いて, バリック法によりモ ニタリング地点の波浪諸元を推定した．図-4に2007年 12 月 10 日〜2008年1月 12 日のモニタリング地点での有義波 高，有義波周期の経時変化を示す，その結果，有義波高 は波高が3mを超える12月30日から1月4日にかけて，津 和崎局, 高崎鼻局の差異が大きくなるとともに, WAM による計算結果ともずれが大きかった.

（4）ドップラスペクトルのエネルギー補正

本来, 同じモニタリング地点で推定された波高 $\left(H_{A V E}\right)$ は，津和崎局，高崎鼻局で同じ值とならなければならな
いため, 前項（3）のバリック法による推定結果の違い は，観測されたドップラスペクトルデータのエネルギー レベルの違いによるものと考えた、今まで観測結果を得 た後に，エネルギーレベルの違いを追及することや，工 ネルギーレベルの補正は行われてこなかった.

そこで, 本研究ではバリック法で求めた高崎鼻局と津 和崎局の波高が同じくなるように，エネルギーレベルの大 きい局に合わせて，エネルギーレベルの小さいドップラス ペクトルに定值を乗じることにより，エネルギーレベルを 調整した。すなわちこの調整を行った後，ドップラスペク トルデータからバリック法により波高・周期を計算すれ ば，津和崎局と高崎鼻局の波高・周期はほほ一致する.

ベイズ法では，ある 1 地点の波高・周期を計算するの に2局のドップラスペクトルデータを必要とする. ベイ ズ法の入力データセットは, バリック法でエネルギーレ ベル調整を行った後の 2 局のドップラスペクトルデータ とした.

\section{（5）ベイズ法による方向スペクトル推定}

前項（4）により，高崎鼻局と津和崎局でのドップラス ペクトルエネルギーレベルの補正後, ベイズ法による方向 スペクトルの推定を行った。 ベイズ法では，方向スペクト ルに周波数と方向角に関する離散的一定值関数を仮定して おり, 周波数分割数 $M$, 方向分割数 $N$ とすると, $M \times N$ 個 の未知パラメータを含む方程式を解く必要がある.

そこで, 本研究では $M=N=8$ として, 方向角に関しては $0 \sim 360$ 度 $(0 \sim 2 \pi)$ の範囲を等分割し, 周波数は 0.05 $1.0 \mathrm{~Hz}$ 等比率で8分割した.

ベイズ法により有義波高，有義波周期を推定した結果 を図-5に示す，推定結果はWAMによるものとほぼ一致 した。また方向スペクトルを推定した結果, WAM, ベイ ズ法とも北西方向の $0.1 \mathrm{~Hz}$ 付近に単峰のエネルギーピー クがみられ，エネルギー分布形状も比較的良く一致した。
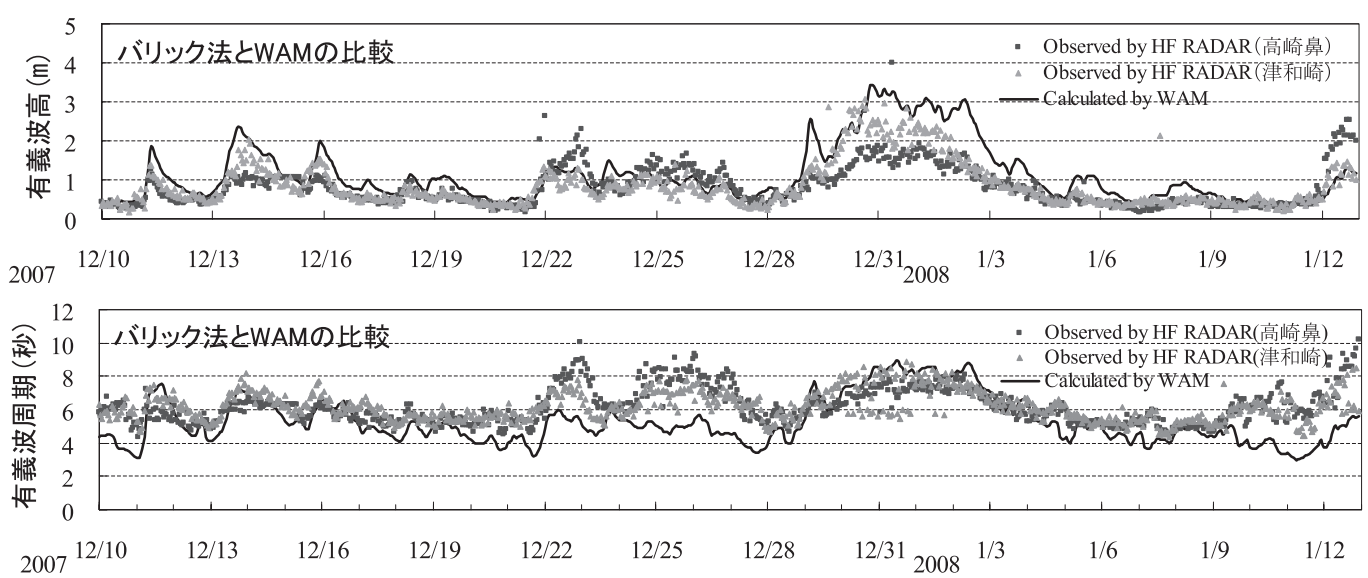

図-4 モニタリング地点でのバリック法とWAMの有義波高・有義波周期の比較 

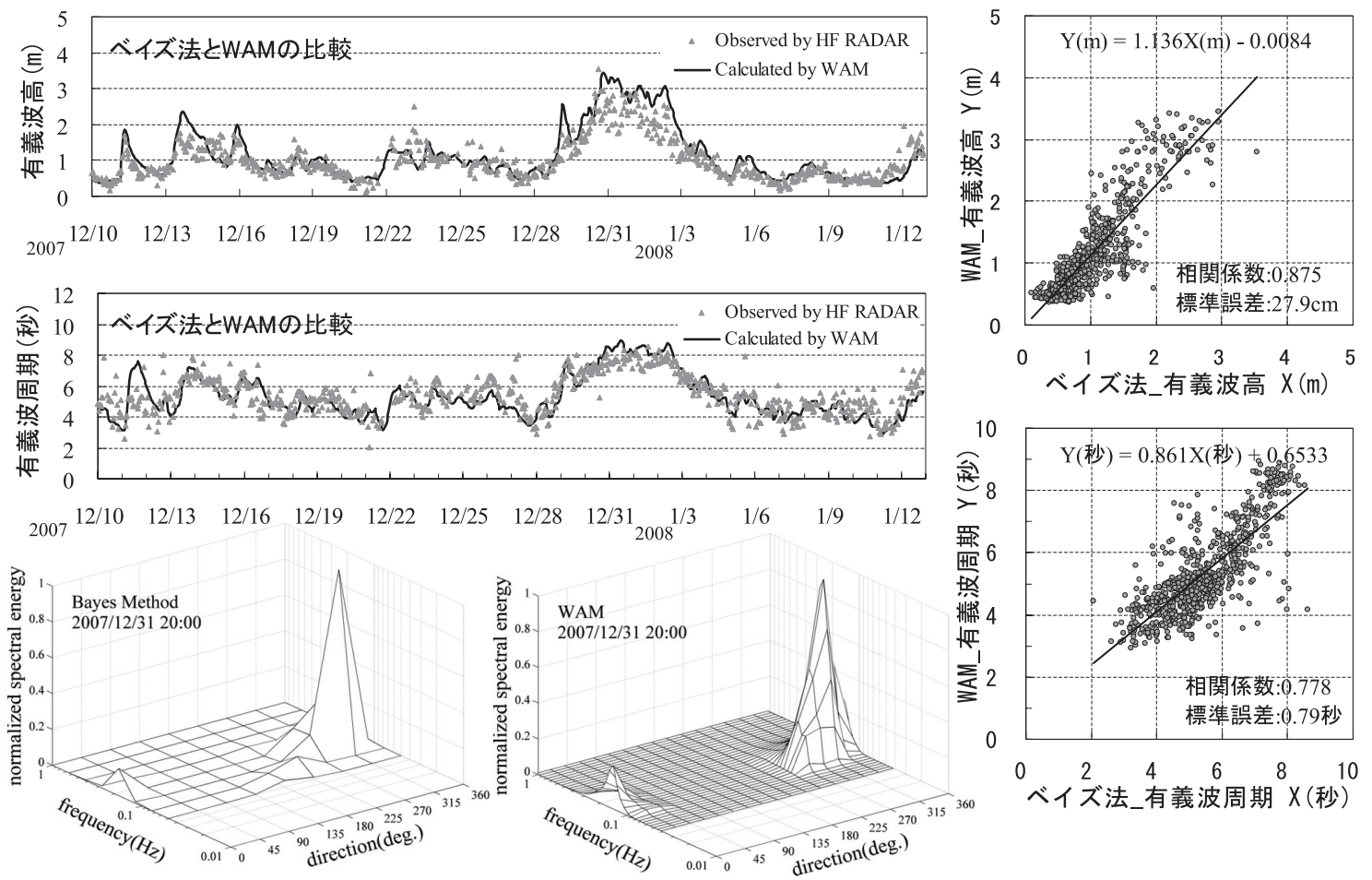

図-5 モニタリング地点でのベイズ法とWAMの有義波高, 有義波周期, および方向スペクトルの比較

\section{6. おわりに}

短波海洋レーダにより五島列島西岸沖で得られたドッ プラスペクトルデータを用いて，波浪推定精度の向上を 行った。まず従来法であるバリック法による波高推定值 のずれに着目し，2局のドップラスペクトルエネルギー が同じくなるようにキャリブレーションを行った。

この補正データをべイズ法に入力した結果，WAMの 推定值と良く一致した波高, 周期および方向スペクトル の推定值を得ることができた。 今後, 短波海洋レーダを 用いた現地観測を実施し, 本研究結果の適用性を検証す るとともに, 実用化に向け, さらなる推定精度の向上を 図る予定である。

なお，本研究で使用した五島列島の短波海洋レーダ観 測データは, 環境省の（旧）地球環境研究総合推進費 (D-071, 平成 19-21年) の援助により取得されたもので ある。

\section{参 考 文 献}

橋本典明・徳田正幸（1998）：海洋短波レーダによる方向スペ クトルの推定, 海岸工学論文集, 第45巻, pp.1271-1275. 橋本典明・児島正一郎・L. R. Wyatt（2000）：海洋短波レーダ 一における方向スペクトルの推定法に関する検討, 海岸 工学論文集，第47巻，pp.1331-1335.

橋本典明・Lukijanto・山城 賢 (2008)：海洋短波レーダにお ける実用的な方向スペクトル推定法の開発, 海岸工学論 文集，第55巻, pp.1451-1455.

橋本典明・Lukijanto・山城 賢 (2010)：海洋短波レーダにお ける方向スペクトル推定法の現地観測データへの適用性 に関する検討, 土木学会論文集 B2 (海岸工学), Vol.66, pp.1411-1415.

日向博文・諸星一信・金津伸好（2008）：HFレーダーによる 漂着ゴミ回収効率化の試み, 沿岸海洋研究, 第 45 号, pp.51-60.

Barrick, D. E (1972) : Remote sensing of sea state by radar, Remote sensing of the Troposphere, V. E. Derr, Editor, U. S. Govt.Printing Office, Washington, D.C., 12.

Barrick, D. E (1977) : Extraction of wave parameters from measured HF radar sea-echo Doppler spectra, Radio Science, Vol. 12, No.3, pp.415-424.

Hisaki, Y (1996) : Nonlinear inversion of the integral equation to estimate ocean wave spectra from HF radar, Radio Science, Vol. 31, No.1, pp. 25-39.

Komen, G.J., L.Cavalieri, M.Donelan, K.Hasselmann, S.Hasselmann and P.A.E.M. Janssen(1994): Dynamics and Modelling of Ocean Waves, Cambridge University Press, 532 p.

Wyatt, L. R. (1990) : A relaxation method for integral inversion applied to HF radar measurement of the ocean wave directional spectral, Int. Jour. Remote Sensing, Vol.11, pp.1481-1494.

Wyatt, L. R. (1997) : The Ocean wave directional spectrum, Oceanography, Vol.10, No.2, pp.85-89. 